\title{
Produksi dan Kualitas Susu Sapi FH Laktasi yang Diberi Pakan Daun Pelepah Sawit
}

\author{
(Milk Production and Its Quality of FH Cows Fed Oil Palm Frond)
}

\author{
P. Riski ${ }^{1)}$ B. P. Purwanto ${ }^{2)}$ \& A. Atabany ${ }^{3)}$ \\ 1) Mahasiswa Program Studi Ilmu Produksi dan Teknologi Peternakan, Sekolah Pascasarjana, Insitut \\ Pertanian Bogor; 2) Program Diploma, Institut Pertanian Bogor; 3) Departemen Ilmu Produksi dan Teknologi \\ Peternakan, Fakultas Peternakan, \\ Institut Pertanian Bogor \\ Jln. Agatis, Kampus IPB Dramaga Bogor 16680, Indonesia
}

\begin{abstract}
This study was done to determine milk production and its quality of FH cows fed oil palm frond (OPF) for 3 months in UPT of Livestock Breeding Station Kampar Riau. 4 x 4 Latin Square design was used in the present study using 4 lactating FH cows and 4 combination of elephant grass and OPF as feeding treatments. The animals were kept in individual stanchion and fed with waste of tofu as concentrate $(\mathbf{4 0} \%$ dry matter base) and roughage (60\% dry matter base). The feeding treatments were $100 \%$ EG, 75\% EG + 25\% OPF, 50\% EG + 50\% OPF and 25\% EG + 75\% OPF. Parameters Measured were feed consumption, milk production and milk quality (density, total solid, fat, solid non-fat and protein). The results showed that feeding of $\mathrm{OPF}$ significantly influenced $(\mathrm{P}<0.01)$ in dry matter and crude protein intakes. Feeding $\mathrm{OPF}$ by $75 \%$ significantly decreased $(\mathrm{P}<0.01)$ milk production. However, there was no effect of any OPF consumption level on milk quality. In was concluded that feeding OPF as feed source of roughage for lactating cow up to $50 \%$ of the total roughage able to maintain milk production and its quality.
\end{abstract}

Key words: feed consumption, milk production, milk quality, oil palm frond

\section{PENDAHULUAN}

Sapi perah yang banyak dipelihara di Indonesia adalah sapi perah Friesian Holstein (FH). Sapi FH merupakan bangsa sapi perah yang memiliki tingkat produksi susu tertinggi dengan kadar lemak yang relatif rendah dibandingkan sapi perah lainnya (Blakely dan Blade 1998). Meningkatkan kapasitas produksi susu dalam negeri diperlukan peningkatan jumlah populasi sapi perah dan produktivitas sapi perah dalam negeri. Produktivitas sapi perah sendiri dipengaruhi oleh beberapa faktor, diantaranya kualitas genetik ternak, tata laksana pemberian pakan, umur beranak pertama, periode laktasi, frekuensi pemerahan, masa kering kandang, dan kesehatan (Schmidt et al. 1988).

Pakan merupakan salah satu faktor penentu utama untuk keberhasilan suatu usaha peternakan. Pakan bagi ternak berfungsi untuk memenuhi kebutuhan hidup pokok, produksi dan reproduksi. Jenis pakan yang diberikan pada sapi perah dapat mempengaruhi produksi dan kualitas susu, serta dapat berpengaruh terhadap kesehatan sapi perah. Pakan untuk sapi perah yang laktasi terdiri atas sejumlah hijauan dan konsentrat (Siregar 2001). Peranan hijauan pakan menjadi lebih penting karena berpengaruh terhadap kadar lemak susu yang dihasilkan. Pemberian hijauan yang lebih banyak menyebabkan kadar lemak susu tinggi karena kadar lemak dalam susu tergantung dari kandungan serat kasar dalam pakan (Arora 1995).

Faktor penyediaan pakan hijauan yang berkualitas masih menjadi kendala karena semakin terbatasnya jumlah lahan untuk penanaman hijauan makanan ternak. Sehingga diupayakan untuk mencari pakan alternatif. Pakan alternatif tersebut harus potensial, murah dan mudah didapat serta tersedia sepanjang tahun. Perkebunan kelapa sawit berpotensi menjadi sumber pakan alternatif untuk mengembangkan usaha peternakan. Provinsi Riau memiliki luas areal perkebunan kelapa sawit terbesar di Indonesia. Luas total perkebunan kelapa sawit di Indonesia sekitar 10.586.500 Ha dan luas areal perkebunan kelapa sawit di Riau mencapai 21\% dengan luas 2.226.600 Ha pada tahun 2013 (BPS 2014). Semakin meningkatnya luas areal maupun produksi kelapa sawit perlu dilakukan pemikiran tentang pemanfaatan perkebunan kelapa sawit tersebut, selain untuk menanggulangi pencemaran lingkungan juga dilihat dari segi ekonomis penggunaan bahan-bahan tersebut dalam ransum ternak akan lebih menguntungkan. Perkebunan kelapa sawit mempunyai potensi cukup besar untuk menyediakan sumber pakan berupa pelepah, daun, maupun limbah dari industri sawit (Daulay $d k k$., 2007). Sementara limbah ternak berupa pupuk kandang merupakan pupuk organik yang sangat baik bagi tanaman kelapa sawit (Umar 2008). Tanaman kelapa sawit dapat menghasilkan 18-25 pelepah/pohon/tahun (Lubis 1992) atau sekitar 10 
ton kering/Ha/tahun (Purba dan Ginting 1997). Pemberian pellet daun pelepah sawit sebanyak $30 \%$ pada sapi perah dapat menghasilkan produksi susu sekitar 366 liter/28hari, kadar lemak 3.5\% dan kadar protein 3.5\% (Abu Bakar et al. 2001).

Peluang bagi peternak untuk memanfaatkan hasil sampingan dan limbah dari perkebunan kelapa sawit berpotensial untuk dijadikan sebagai pakan alternatif untuk ternak karena masih tersedia dalam jumlah yang banyak, belum dimanfaatkan secara optimal dan tersedia sepanjang tahun serta dapat menanggulangi pencemaran lingkungan dari limbah hasil perkebunan dan hasil produksi kelapa sawit. Penelitian ini bertujuan untuk mempelajari performa produksi dan kualitas susu meliputi kadar protein, berat jenis (BJ), kadar lemak, bahan kering (BK), dan bahan kering tanpa lemak/solid non fat (BKTL) sapi FH laktasi yang diberi pakan daun pelepah sawit.

\section{MATERI DAN METODE}

\section{Waktu dan Tempat Penelitian}

Penelitian ini dilaksanakan pada bulan Desember 2015 sampai Februari 2016. Lokasi penelitian dilaksanakan di UPT Balai Pembibitan Peternakan Kabupaten Kampar Provinsi Riau. Uji Proksimat pakan dilakukan di Laboratorium Ilmu Nutrisi dan Kimia Fakultas Pertanian dan Peternakan Universitas Islam Negeri Sultan Syarif Kasim Riau. Uji kualitas susu dilakukakn di Laboratorium Pengujian dan Sertifikasi Mutu barang Dinas Perindustrian dan Perdagangan Provinsi Riau.

\section{Prosedur Penelitian}

Ternak yang digunakan pada penelitian adalah Sapi FH laktasi pertama bulan kelima sebanyak 4 ekor ternak dengan estimasi umur 24-36 bulan yang berada di UPT Balai Pembibitan Peternakan Kabupaten Kampar Provinsi Riau dipelihara dan diberikan pakan hijauan rumput raja (RR) dan daun pelepah sawit (DPS) dengan konsentrasi berbeda ( $\mathrm{A}=\mathrm{RR} 100 \%$ sebagai kontrol, $\mathrm{B}=\mathrm{RR} 75 \%+\mathrm{DPS} 25 \%$, $\mathrm{C}=\mathrm{RR} 50 \%+\mathrm{DPS} 50 \%$ dan D $=\mathrm{RR} 25 \%+\mathrm{DPS} 75 \%$ ) pada tiap-tiap perlakuan selama 21 hari, masa adaptasi pakan selama dua minggu (14 hari) yang dilanjutkan untuk pengumpulan data selama 7 hari terakhir.

Ternak sapi FH laktasi melalui tahapan penyesuaian terhadap perubahan pakan (pre-eliminary) selama dua minggu sebelum diberikan perlakuan. Tahap ini bertujuan untuk mengurangi pengaruh pakan yang diberikan selama perlakuan terhadap peubah yang diamati. Persiapan pemeliharaan meliputi pembersihan kandang, menentukan ternak sapi FH laktasi yang akan dijadikan sebagai ternak penelitian dan persiapan pakan. Pakan hijauan berupa daun pelepah sawit sebelum diberikan ke ternak terlebih dahulu dicacah menggunakan chopper.

Pemberian pakan sebanyak $\pm 3 \%$ dari perkiraan bobot hidup dan penghitungan kebutuhan gizi pakan mengacu pada petunjuk Nutrient Requirements of Dairy Cattle (NRC 2001). Rasio hijauan dan konsentrat adalah 60\% : 40\%. Konsentrat yang diberikan adalah ampas tahu. Pakan diberikan dua kali sehari yaitu pukul 08.00 dan 15.00 WIB. Pemberian air minum disediakan adlibitum. Konsumsi pakan dan sisa pakan ditimbang setiap hari. Produksi susu per hari diukur dengan mencatat hasil pemerahan pada pagi dan sore hari. Sampel susu diambil pada awal penelitian (sebelum perlakuan), awal perlakuan (hari ke-1 perlakuan), pertengahan perlakauan (hari ke-3 perlakuan) dan akhir penelitian (setelah 7 hari perlakuan) untuk uji kualitas susu.

\section{Peubah yang Diamati}

\section{Konsumsi Pakan}

Konsumsi pakan diukur dengan menghitung selisih antara pakan yang diberikan dikurangi dengan pakan sisa. Pengukuran konsumsi pakan dilakukan setiap hari selama penelitian pada masing-masing ternak sapi FH perlakuan. Perhitungan konsumsi bertujuan untuk mengetahui konsumsi Bahan Kering (BK) dan nutrient pakan seperti protein. Perhitungan konsumsi Bahan Kering (BK) dan komposisi nutrient pakan (McDonald et al. 2002) adalah:

Konsumsi BK pakan $=[$ pakan yang diberikan $(\mathrm{g})-$ sisa pakan $(\mathrm{g})]$ x \% BK pakan

Konsumsi Nutrien (g/ekor/hari) = konsumsi BK pakan (g/ ekor/hari) x \% kadar nutien

\section{Produksi Susu}

Produksi susu diperoleh dengan cara mencatat hasil pemerahan empat ekor sapi FH laktasi masing-masing pada pagi dan sore hari. Pengukuran dimulai setelah masa persiapan (pre-eliminary) sampai dengan akhir masa pemeliharaan. Pengukuran produksi susu dilakukan dengan menggunakan gelas ukur berskala.

\section{Kualitas Susu}

Pengujian kualitas susu sapi FH meliputi berat jenis, analisis kadar lemak, bahan kering, bahan kering tanpa lemak dan analisis kadar protein. Uji kualitas susu dilakukakn di Laboratorium Pengujian dan Sertifikasi Mutu barang Dinas Perindustrian dan Perdagangan Provinsi Riau. Sampel susu yang digunakan sebanyak 1 liter.

\section{Analisis Data}

Pengaruh perlakuan pemberian pakan daun pelepah sawit terhadap performa produksi dan kualitas susu sapi FH dianalisis menggunakan sidik ragam (Anova). Perbedaan nilai rataan pada peubah yang diukur dari setiap perlakuan diketahui melalui uji perbandingan berganda uji Tukey.

Parameter THI (Temperature Humidity Index) disusun secara deskriptif. Terdapat dua faktor dalam percobaan ini yaitu individu sapi dan perlakuan, sehingga digunakan Rancangan Bujur Sangkar Latin 4 X 4 berupa 4 ekor sapi FH laktasi dan 4 Perlakuan pakan:
A: (100\% hijauan rumput + konsentrat) sebagai kontrol B: $(75 \%$ rumput $+25 \%$ daun pelepah sawit + konsentrat $)$ C: (50\% rumput $+50 \%$ daun pelepah sawit + konsentrat $)$ D: $(25 \%$ rumput $+75 \%$ daun pelepah sawit + konsentrat $)$

\section{HASIL DAN PEMBAHASAN}

Hasil penelitian menunjukkan kondisi Mikroklimat selama penelitian di UPT Balai Pembibitan Peternakan Kabupaten Kampar Provinsi Riau ditampilkan pada Tabel 1. 
Tabel 1 Kondisi Mikroklimat selama penelitian

\begin{tabular}{lc}
\hline Peubah & Rataan (Min-Max) \\
\hline Suhu Lingkungan $\left({ }^{\circ} \mathrm{C}\right)$ & $30.44 \pm 2.90(22-39)$ \\
Suhu Kandang $\left({ }^{\circ} \mathrm{C}\right)$ & $28.81 \pm 2.21(22-34)$ \\
Kelembaban $(\%)$ & $79.65 \pm 10.12(54-92)$ \\
Temperature Humidity Index & $82.51 \pm 3.17(71.30-92.00)$ \\
(THI) Lingkungan & \\
Temperature Humidity Index & $80.32 \pm 2.10(71.30-88.60)$ \\
(THI) Kandang & \\
\hline
\end{tabular}

Berdasarkan hasil pengamatan kondisi mikroklimat di UPT Balai Pembibitan Peternakan Kabupaten Kampar Provinsi Riau diketahui suhu lingkungan dan kandang masing-masing $30.44^{\circ} \mathrm{C}$ dan $28.81^{\circ} \mathrm{C}$ berada diatas kondisi nyaman (zona termonetral) untuk sapi perah $\mathrm{FH}$ yang berkisar $13-25^{\circ} \mathrm{C}$ (Yani dan Purwanto 2006) dan suhu kritis pada sapi perah $\mathrm{FH}$ yaitu $27^{\circ} \mathrm{C}$ (Hadisusanto 2006). Kelembaban di UPT berkisar $79.65 \%$ berada pada kelembaban ideal untuk ternak sapi perah FH yaitu $60-80 \%$ (Soetarno 2003). Nilai Temperature Humidity Index (THI) lingkungan dan kandang di UPT masing-masing 82.51 dan 80.32 berada diatas nilai THI normal (kondisi nyaman) sapi perah FH. Nilai THI normal (kondisi nyaman) untuk sapi FH adalah berada dibawah 72 dan sapi FH akan mengalami stress panas jika melewati angka 72 (Rejeb et al. 2012; Amir 2010; Yani et al. 2007; Moran 2005; Dobson et al. 2003 ; Armstrong 1994).

Berdasarkan kondisi Mikroklimat berupa suhu, kelembaban dan Temperature Humidity Index (THI) dapat

Tabel 2 Nilai rata-rata konsumsi pakan selama penelitian

\begin{tabular}{|c|c|c|c|c|}
\hline \multirow[t]{2}{*}{ Keterangan } & \multicolumn{4}{|c|}{ Pemberian DPS } \\
\hline & $0 \%($ Kontrol $)$ & $25 \%$ & $50 \%$ & $75 \%$ \\
\hline \multicolumn{5}{|l|}{ Pemberian Pakan (kg) } \\
\hline \multicolumn{5}{|l|}{ Hijauan } \\
\hline DPS & - & $3.73 \pm 0.06$ & $7.49 \pm 0.13$ & $11.23 \pm 0.19$ \\
\hline Rumput raja & $32.77 \pm 0.56$ & $24.58 \pm 0.42$ & $16.39 \pm 0.28$ & $8.19 \pm 0.14$ \\
\hline Ampas tahu & $15.78 \pm 0.27$ & $15.78 \pm 0.27$ & $15.78 \pm 0.27$ & $15.78 \pm 0.27$ \\
\hline \multicolumn{5}{|l|}{ Sisa pakan $(\mathrm{kg})$} \\
\hline DPS & - & $1.17 \pm 0.07$ & $3.84 \pm 0.51$ & $6.50 \pm 0.37$ \\
\hline Rumput raja & $12.32 \pm 0.65$ & $7.40 \pm 0.22$ & $4.48 \pm 0.54$ & $3.56 \pm 0.69$ \\
\hline Ampas tahu & 0 & 0 & 0 & 0 \\
\hline \multicolumn{5}{|c|}{ Konsumsi pakan (g/ekor/hari) } \\
\hline Bahan kering & $8788.48 \pm 279^{a b}$ & $9162.27 \pm 217^{a}$ & $8433.29 \pm 161^{b}$ & $7557.19 \pm 269^{b}$ \\
\hline Hijauan & $4195.33 \pm 212^{\mathrm{ab}}$ & $4679.52 \pm 147^{a}$ & $3950.55 \pm 169^{b}$ & $3074.44 \pm 268^{c}$ \\
\hline DPS & - & $1154.09 \pm 51$ & $1506.68 \pm 104$ & $2122.93 \pm 131$ \\
\hline Rumput raja & $4195.33 \pm 212$ & $3525.43 \pm 98$ & $2443.85 \pm 147$ & $951.50 \pm 138$ \\
\hline Ampas tahu & $4482.75 \pm 76$ & $4482.75 \pm 76$ & $4482.75 \pm 76$ & $4482.75 \pm 76$ \\
\hline Protein Kasar & $1465.75 \pm 42^{\mathrm{a}}$ & $1439.13 \pm 30^{\mathrm{a}}$ & $1313.05 \pm 30^{\mathrm{b}}$ & $1146.22 \pm 28^{c}$ \\
\hline Hijauan & $564.27 \pm 28^{\mathrm{a}}$ & $537.64 \pm 16^{\mathrm{a}}$ & $411.56 \pm 19^{b}$ & $244.74 \pm 26^{c}$ \\
\hline DPS & - & $63.47 \pm 5$ & $82.86 .8 \pm 15$ & $116.76 \pm 7$ \\
\hline Rumput raja & $564.27 \pm 28$ & $474.17 \pm 13$ & $328.69 \pm 19$ & $127.79 \pm 18$ \\
\hline Ampas tahu & $901.48 \pm 15$ & $901.48 \pm 15$ & $901.48 \pm 15$ & $901.48 \pm 15$ \\
\hline
\end{tabular}

Keterangan: superskrip yang berbeda pada baris yang sama menunjukkan perbedaan sangat nyata $(\mathrm{P}<0.01)$. diketahui Sapi FH yang dipelihara di UPT Balai Pembibitan Peternakan Kabupaten Kampar mengalami cekaman/stress panas. Pengaruh yang timbul pada sapi FH yang terkena cekaman/stress panas adalah 1) penurunan nafsu makan; 2) peningkatan konsumsi minum; 3) penurunan metabolisme dan peningktan katabolisme; 4) peningkatan pelepasan panas melalui penguapan; 5) penurunan konsentrasi hormon dalam darah; 6) peningkatan temperatur tubuh, respirasi dan denyut jantung; dan 7) perubahan tingkah laku, meningkatnya intensitas berteduh sapi (Rejeb et al. 2012; Amstrong 1994).

\section{Konsumsi Pakan}

Pakan merupakan salah satu faktor penting dalam usaha peternakan. Jenis pakan yang diberikan akan mempengaruhi produksi, kualitas susu dan kesehatan sapi perah (Siregar 2001). Pakan yang digunakan pada penelitian ini terdiri dari $60 \%$ hijauan dan $40 \%$ konsentrat berupa ampas tahu. Pakan hijauan yang diberikan terdiri dari rumput raja dan daun pelepah sawit. Pemberian daun pelepah sawit terdiri dari $3.73 \pm 0.06 \mathrm{~kg}(25 \%), 7.49 \pm 0.13 \mathrm{~kg}(50 \%)$ dan $11.23 \pm 0.19 \mathrm{~kg}(75 \%)$. Pemberian rumput raja yaitu $32.77 \pm 0.56 \mathrm{~kg}(100 \%), 24.58 \pm 0.42 \mathrm{~kg}(75 \%), 16.39 \pm 0.28$ $\mathrm{kg}(50 \%)$ dan $8.19 \pm 0.14 \mathrm{~kg}(25 \%)$. Pemberian konsentrat sekitar $15.78 \pm 0.27 \mathrm{~kg}$. Pada sapi laktasi, konsumsi pakan sangat penting untuk memproduksi susu yang maksimal. Kondisi lingkungan yang nyaman akan menghasilkan susu yang baik. Berikut ditampilkan rata-rata konsumsi pakan selama penelitian pada Tabel 2 .

Berdasarkan analisis sidik ragam (Tabel 2) menunjukkan pemberian pakan daun pelepah sawit 
berpengaruh sangat nyata $(\mathrm{P}<0.01)$ terhadap konsumsi bahan kering pakan dan konsumsi protein kasar pakan. Pemberian pakan daun pelepah sawit sebanyak 50\% dan $75 \%$ dari total hijauan menunjukkan konsumsi bahan kering yang nyata lebih rendah dibandingkan pemberian $0 \%$ dan $25 \%$. Untuk konsumsi protein kasar perlakuan pemberian daun pelepah sawit $50 \%$ dan $75 \%$ sangat nyata $(\mathrm{P}<0.01)$ lebih sedikit dibandingkan perlakuan lainnya. Semakin banyak konsentrasi pemberian daun pelepah sawit nyata menurunkan konsumsi bahan kering dan protein kasar pakan. Konsumsi bahan kering DPS pada pemberian 25\%, $50 \%$ dan $75 \%$ masing-masing $68.64 \%$, 48.74\% dan $42.20 \%$ menunjukkan semakin banyak pemberian DPS menurunkan konsumsi dan menunjukkan rasa suka (palatabilitas) yang rendah.

Berdasarkan NRC (2001), kebutuhan konsumsi bahan kering pakan sapi laktasi sebesar $12.4 \mathrm{~kg}$ menghasilkan susu $10 \mathrm{~kg}$, dibandingkan dengan nilai konsumsi bahan kering pakan penelitian masih dibawah nilai kebutuhan sapi (rata-rata konsumsi bahan kering sebesar $8.48 \pm 0.231 \mathrm{~kg}$ dan produksi susu sebesar $3.64 \pm 0.33 \mathrm{~kg}$ ). Hal ini diduga dapat disebabkan oleh beberapa faktor, diantaranya rasa suka (palatabilitas) pakan daun pelepah sawit yang rendah dan terjadinya cekaman panas pada sapi sapi FH yang dipelihara di UPT Balai Pembibitan Peternakan Kabupaten Kampar provinsi Riau yang berdampak sapi lebih banyak minum daripada makan, dapat dilihat dari persentase konsumsi BK pakan hanya sekitar $2.27 \pm 0,18 \%$ dari bobot badan. Hal tersebut dilakukan untuk menurunkan kondisi suhu tubuh sapi.

Pakan yang mengandung konsentrat tinggi akan meningkatkan produksi susu sapi perah, sedangkan pemberian hijauan dalam jumlah yang cukup akan berpengaruh terhadap kadar lemak susu, karena hijauan akan diubah oleh mikroba rumen menjadi VFA yang terdiri atas $65 \%$ asam asetat, $20 \%$ asam propionat dan $15 \%$ asam butirat (Barret dan Larkin 1979).

\section{Produksi dan Kualitas Susu}

Berdasarkan analisis sidik ragam (Tabel 3), pemberian pakan daun pelepah sawit sebanyak $75 \%$ dari total hijauan berpengaruh sangat nyata $(\mathrm{P}<0.01)$ terhadap produksi susu sapi FH. Pada pemberian pakan daun pelepah sawit $75 \%$ memiliki produksi susu yang rendah dibandingkan dengan pemberian daun pelepah sawit $0 \%$, $25 \%$ dan $50 \%$. Nilai produksi susu yang rendah dapat disebabkan oleh beberapa faktor, salah satunya yaitu rendah konsumsi ternak dalam mengkonsumsi pakan (palatabilitas) dan kualitas nutrisi daun pelepah sawit yang lebih rendah. Data konsumsi barang kering dan konsumsi protein kasar pada pemberian pakan DPS 50\% dan DPS 75\% nyata lebih rendah dibandingkan pemberian DPS $25 \%$ dan perlakuan kontrol (tanpa pemberian daun pelepah sawit).

Kondisi lingkungan juga berpengaruh terhadap kondisi tubuh sapi. Sapi dengan kondisi nyaman akan menghasilkan susu yang baik. Berdasarkan data mikroklimat diketahui Sapi FH yang dipelihara di UPT Balai Pembibitan Peternakan Kabupaten Kampar mengalami cekaman/stress panas yang diduga juga mempengaruhi rendahnya produksi susu.

Pemberian pakan DPS 25\% dan DPS 50\% dari total hijauan menunjukkan produksi susu yang tidak jauh berbeda atau sebanding dengan pakan tanpa pemberian daun pelepah sawit (kontrol). Hal ini menunjukkan sapi FH laktasi mampu mempertahankan produksi susunya sampai pemberian daun pelepah sawit sebanyak 50\% dari total hijaun yang diberikan.

Pemberian daun pelepah sawit sebagai pakan sapi FH laktasi menunjukkan hasil yang tidak berpengaruh nyata $(\mathrm{P}>0.05)$ terhadap kualitas susu (Berat jenis, bahan kering, lemak, BKTL dan protein). Pada Tabel 3 dapat dilihat hasil kualitas susu (BJ, lemak dan protein) sapi FH yang diberi pakan daun pelepah sawit masih berada pada kisaran normal sesuai dengan SNI 01-3141-1998: Susu Segar. Menurut SNI susu segar syarat minimum BJ susu pada sapi perah adalah 1.0280. Kadar lemak susu segar adalah 3.0\%. Standar kadar protein susu sapi perah adalah 2.7\% (Badan Standarisasi Nasional 1998). Nilai BKTL setiap perlakuan menunjukkan nilai yang berada dibawah SNI yaitu 7.8. Hal ini diduga karena kandungan laktosa yang rendah pada susu sapi FH hasil penelitian. Laktosa merupakan disakarida yang terdiri dari glukosa dan galaktosa (Solomons 2002). Hasil hidrolisa laktosa yang berupa galaktosa adalah senyawa yang penting untuk pembentukan sebrosida. Sebrosida penting untuk perkembangan dan fungsi otak (Sinuhaji 2006).

Berat jenis susu erat kaitannya dengan komponen padatan susu dan bahan kering konsentrat dalam ransum. Semakin tinggi persentase bahan kering ransum menghasilkan berat jenis susu yang semakin besar. Berat jenis susu dipengaruhi oleh komponen susu terutama lemak, karena berat jenis lemak lebih rendah dari pada air. Semakin tinggi kadar lemak dalam susu menyebabkan berat jenis susu yang rendah. Pakan hijauan menyebabkan

Tabel 3 Nilai rata-rata produksi dan kualitas susu sapi FH yang diberi pakan perlakuan

\begin{tabular}{lcccc}
\hline Keterangan & \multicolumn{4}{c}{ Pemberian DPS (Daun Pelepah Sawit) } \\
\cline { 2 - 5 } & $0 \%($ Kontrol) & $25 \%$ & $50 \%$ & $75 \%$ \\
\hline Produksi susu & $3.94 \pm 0.52^{\mathrm{a}}$ & $3.82 \pm 0.63^{\mathrm{a}}$ & $3.61 \pm 0.69^{\mathrm{a}}$ & $3.18 \pm 0.50^{\mathrm{b}}$ \\
Berat jenis (g/ml) & $1.03 \pm 0.001$ & $1.03 \pm 0.001$ & $1.03 \pm 0.001$ & $1.03 \pm 0.001$ \\
Bahan kering (\%) & $10.89 \pm 0.48$ & $10.78 \pm 0.54$ & $10.94 \pm 0.64$ & $10.85 \pm 0.05$ \\
Lemak (\%) & $3.03 \pm 0.37$ & $3.05 \pm 0.32$ & $2.95 \pm 0.20$ & $3.00 \pm 0.17$ \\
BKTL (\%) & $7.69 \pm 0.27$ & $7.64 \pm 0.35$ & $7.73 \pm 0.30$ & $7.70 \pm 0.16$ \\
Protein (\%) & $3.05 \pm 0.14$ & $2.89 \pm 0.07$ & $3.09 \pm 0.39$ & $3.04 \pm 0.22$ \\
\hline Keterang
\end{tabular}

Keterangan: superskrip yang berbeda pada baris yang sama menunjukkan perbedaan sangat nyata $(\mathrm{P}<0.01)$. 
kadar lemak susu tinggi karena lemak susu tergantung dari kandungan serat kasar dalam pakan (Sudono et al. 2003) dan pemberian konsentrat akan meningkatkan protein susu sehingga berat jenis susu meningkat. Berat jenis susu juga sangat dipengaruhi oleh berat jenis komponen penyusun susu seperti protein, laktosa dan mineral (Sukarni 2006).

Peningkatan kadar protein pada susu tergantung pada asupan protein dalam pakan ternak yang membentuk asam amino dan diserap tubuh melalui darah (Mc Donald et al. 2002). Nilai protein susu dipengaruhi oleh pemberian konsentrat. Semakin tinggi pemberian konsentrat maka semakin tinggi kadar protein susu (Sukarni 2006). Kandungan kadar protein susu berkorelasi positif terhadap energi pakan, terutama karbohidrat yang mudah larut. Ketersediaanya menfasilitasi pembentukan propionat sehingga menurunkan kebutuhan asam amino untuk glukoneogenesis yang menjadikan asam amino lebih banyak tersedia di usus halus dan sintesa protein di kelenjat susu (Sukarni 2006; Utari et al 2012).

\section{KESIMPULAN}

Perlakuan terbaik pemberian pakan daun pelepah sawit untuk sapi FH laktasi adalah 25\% dari total hijaun. Maksimal Pemberian daun pelepah sawit sebagai pakan sapi FH laktasi sampai 50\% dari total pakan hijauan mampu mempertahankan produksi dan kualitas susu. Rasa suka (palatabilitas) daun pelepah sawit sebagai pakan ternak sapi perah FH tergolong rendah. Pemanfaatan daun pelepah sawit sebagai pakan alternatif untuk ternak perah perlu dilakukan penelitian lebih lanjut berupa pengolahan secara fisik dan kimia atau kombinasi keduanya guna meningkatkan pemanfaatan dan kualitas daun pelapah sawit.

\section{DAFTAR PUSTAKA}

Abu Bakar C, Yusof SM, Hayakawa H, Zahari MW, Sukri IM, Shukri I. 2001. Lactations responses of graded Shahiwal-Friesians fed pelleted OPF as complete feed. Proc. $23^{\text {rd }}$ MSAP Ann. Conf., Langkawi, Malaysia.

Amir A. 2010. Respon termoregulasi dan tingkah laku bernaung sapi perah dara peranakan Fries Holland pada energi ransum yang berbeda [tesis]. Bogor (ID): IPB.

Amstrong DV. 1994. Heat stress interaction with shade ang cooling. J Diary Sci. 77: 2044-2050.

Arora SP. 1995. Percernaan Mikroba pada Ruminansia. Yogyakarta (ID): UGM Pr.

Badan Standarisasi Nasional. 1998. Standar Nasional Indonesia 01-3141-1998: Susu Segar. Jakarta (ID). Departemen Perindustrian Indonesia.

Blakely J, Blade DH. 1998. Ilmu Peternakan. Srigandono B, penerjemah; Sudarsono, editor. Ed ke- 4. Yogyakarta (ID). UGM Pr.

BPS. 2014. Luas Tanaman Perkebunan Menurut Propinsi dan Jenis Tanaman. Jakarta (ID). Badan Pusat Statistik Indonesia.

Daulay AH, Sembiring I, Manurung L. 2007. Analisis ekonomi uji ransum berbasis pelepah daun sawit, jerami padi dan jerami jagung fermentasi dengan phanerochaete chrysosporium pada sapi peranakan ongole. Jurnal agribisnis peternakan, vol. 3, no. 2, agustus 2007.

Dobson H, Ghuman SPS, Prabhaker S, Smith RF. 2003. A conceptual model of the influence of stress on female reproduction [ulasan]. J Reproduction. 125:151-163.

Hadisusanto B. 2006. Studi tentang beberapa performan reproduksi pada berbagai paritas induk dalam formulasi masa kosong (days open) sapi perah Fries Holland [disertasi]. Bandung (ID): Universitas Padjadjaran.

Lubis AU. 1992. Kelapa Sawit (Elaeis Guineensis. Jacq.) Di Indonesia. Pusat Penelitian Perkebunan MarihatBandar Kuala. Sumatera Utara (ID).

McDonald P, Edwards RA, Greenhalgh JFD, Morgan CA. 2002. Animal Nutrition. $6^{\text {th }}$ Ed. London (GB). Pretice all.

Moran J. 2005. Tropical Diary Farming. Feeding Management for Small Holder Diary Farming in the Humid Tropics. Collingwood (AU): Landlink Pr.

[NRC] National Research Council. 2001. Nutrients Requerement of Diary Cattle. Edisi Ke-7. Washington DC (US).

Rejeb M, Najar T, M'Rad MB. 2012. The effect of heta stress on diary cow's performance and animal behaviour. IJAPES. 2(3):29-34.

Schmidt GH, Van Vleck LD, Hutjens MP. 1988. Principles of Dairy Science. 2th Ed. New Jersey (US): Prentice Hall.

Siregar SB. 2001. Peningkatan kemampuan berproduksi susu sapi perah laktasi melalui perbaikan pakan dan frekuensi pemberiannya. JITV. 6(2):76-82.

Soetarno T. 2003. Manajemen Budidaya Sapi Perah. Yogyakarta (ID): Universitas Gadjah Mada.

Sudono A, Rosdiana RF, Setiawan BS. 2003. Beternak Sapi Perah Secara Intensif. Jakarta (ID). Agromedia Pustaka.

Sukarni. 2006. Produksi dan kualitas air susu kambing Peranakan Ettawa yang diberi tambahan urea molases blok dan atau dedak padi pada awal laktasi. J Animal Production. 1: 427-441.

Umar S. 2008. Potensi limbah kelapa sawit dan pengembangan peternakan sapi berkelanjutan di kawasan perkebunan kelapa sawit. Jurnal wawasan, februari 2008, volume 13. Nomor 3.

Utari FD, Prasetiyono BWHE, Muktini A. 2012. Kualitas susu kambing perah Peranakan Ettawa yang diberi suplementasi protein terproteksi dalam wafer pakan komplit berbasis lombah agroindustri. J Animal Agriculture. 1: 427-441.

Yani A. Purwanto BP. 2006. Pengaruh iklim terhadap respon sapi peranakan Fries Holland dan modifikasi lingkungan untuk meningkatkan produktivitasnya. Media Petern. 9:35-46.

Yani A, Suhardiyanto, Hasbullah R, Purwanro BP. 2007. Analisis dan simulasi distribusi suhu udara pada kandang sapi perah menggunakan Computational Fluid Dynamics (CFD). Media Petern. 30:218-228. 